\title{
Simultaneous measurements of $\mathrm{OClO}, \mathrm{NO}_{2}$ and $\mathrm{O}_{3}$ in the Arctic polar vortex by the GOMOS instrument
}

\author{
C. Tétard ${ }^{1}$, D. Fussen ${ }^{1}$, C. Bingen ${ }^{1}$, N. Capouillez ${ }^{1}$, E. Dekemper ${ }^{1}$, N. Loodts ${ }^{1}$, N. Mateshvili ${ }^{1}$, F. Vanhellemont ${ }^{1}$, \\ E. Kyrölä ${ }^{2}$, J. Tamminen ${ }^{2}$, V. Sofieva ${ }^{2}$, A. Hauchecorne ${ }^{3}$, F. Dalaudier ${ }^{3}$, J.-L. Bertaux ${ }^{3}$, O. Fanton d'Andon ${ }^{4}$, \\ G. Barrot ${ }^{4}$, M. Guirlet ${ }^{4}$, T. Fehr ${ }^{5}$, and L. Saavedra ${ }^{5}$ \\ ${ }^{1}$ Institut d'Aéronomie Spatiale de Belgique, Brussels, Belgium \\ ${ }^{2}$ Finnish Meteorological Institute, Helsinki, Finland \\ ${ }^{3}$ Service d'Aéronomie du CNRS, Verrières-le-buisson, France \\ ${ }^{4}$ ACRI-ST, Sophia-Antipolis, France \\ ${ }^{5}$ European Space Research Institute (ESRIN), European Space Agency, Frascaty, Italy
}

Received: 7 May 2009 - Published in Atmos. Chem. Phys. Discuss.: 4 June 2009

Revised: 25 September 2009 - Accepted: 3 October 2009 - Published: 20 October 2009

\begin{abstract}
We present the first nighttime measurements of $\mathrm{OClO}$ from a limb-viewing satellite instrument in the Arctic polar vortex. The relationship between $\mathrm{OClO}, \mathrm{NO}_{2}$ and $\mathrm{O}_{3}$ slant column densities in the Arctic polar vortex are analyzed from the GOMOS measurements. The retrieval process is based on a differential optical absorption spectroscopy (DOAS) method applied on the weighted median GOMOS transmittances. A study of the longitudinal distributions of $\mathrm{OClO}, \mathrm{NO}_{2}$ and $\mathrm{O}_{3}$ above $65^{\circ}$ north in January 2008 is presented. It shows a strong halogen activation in the lower stratosphere and a strong denoxification in the entire stratosphere inside the Arctic polar vortex. Time series of temperatures and $\mathrm{OClO}, \mathrm{NO}_{2}$ and $\mathrm{O}_{3}$ slant column densities for the winters 2002/2003 to 2007/2008 are also presented. They highlight the correlation between temperature, $\mathrm{OClO}$ and $\mathrm{NO}_{2}$. The GOMOS instrument appears to be a very suitable instrument for the monitoring of $\mathrm{OClO}, \mathrm{NO}_{2}$ and $\mathrm{O}_{3}$ in the stratosphere during nighttime.
\end{abstract}

\section{Introduction}

Since the discovery of stratospheric ozone depletion by Farman et al. (1985), several studies have been performed to better understand this recurrent phenomenon (a historical review of this research can be found in Solomon, 1999). Inorganic chlorine species $\left(\mathrm{Cl}_{\mathrm{y}}\right)$ play an important role in the strato-

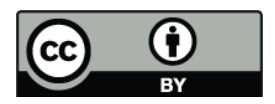

Correspondence to: C. Tétard (cedric.tetard@aeronomie.be) spheric chemical processes that lead to ozone depletion in both Arctic and Antarctic polar regions. The inert reservoir species (like $\mathrm{ClONO}_{2}$ or $\mathrm{HCl}$ ) are converted into active chlorine $\left(\mathrm{ClO}, \mathrm{Cl}_{2} \mathrm{O}_{2}\right)$ by heterogeneous reactions, which occur on the surface of polar stratospheric clouds (PSCs) formed during the polar night (Solomon et al., 1986) if stratospheric temperatures are below $195 \mathrm{~K}\left(T_{\mathrm{PSC}}\right.$ at $\left.50 \mathrm{hPa}\right)$. These active species strongly contribute to catalytic cycles that destroy ozone. A consequence of the halogen activation is the production of $\mathrm{OClO}$ via one of the three reactions between $\mathrm{ClO}$ and $\mathrm{BrO}$ :

$$
\begin{aligned}
& \mathrm{ClO}+\mathrm{BrO} \rightarrow \mathrm{OClO}+\mathrm{Br} \\
& \mathrm{ClO}+\mathrm{BrO} \rightarrow \mathrm{BrCl}+\mathrm{O}_{2} \\
& \mathrm{ClO}+\mathrm{BrO} \rightarrow \mathrm{Br}+\mathrm{Cl}+\mathrm{O}_{2}
\end{aligned}
$$

The study done by Sessler et al. (1995) shows that OClO is a good qualitative indicator of chlorine activation and a good quantitative indicator of $\mathrm{BrO}$. This study highlights also that $\mathrm{OClO}$ is a poor quantitative indicator of $\mathrm{ClO}$ presence. The monitoring of OClO appears to be crucial to better understand the chemistry of the halogen species in the stratosphere. The only significant sink of $\mathrm{OClO}$ is its rapid photolysis by solar radiation in the UV wavelength range. Consequently $\mathrm{OClO}$ is almost constant during the night.

Nitrogen species $\mathrm{NO}_{\mathrm{x}}\left(\mathrm{NO}+\mathrm{NO}_{2}\right)$ also play an important role by reforming the halogen reservoir species:

$$
\begin{aligned}
& \mathrm{ClO}+\mathrm{NO}_{2} \rightarrow \mathrm{ClONO}_{2} \\
& \mathrm{BrO}+\mathrm{NO}_{2} \rightarrow \mathrm{BrONO}_{2}
\end{aligned}
$$

Published by Copernicus Publications on behalf of the European Geosciences Union. 
Reactions (R4) and (R5) limit the formation of OClO. Nevertheless, in the polar vortex, $\mathrm{NO}_{2}$ is removed via the formation of $\mathrm{HNO}_{3}$ on the surface of PSCs. This is the wellknown denoxification of the polar vortex. This denoxification causes a delay in chlorine deactivation and a more prolonged period of ozone loss.

The first measurements of $\mathrm{OClO}$ in the stratosphere were performed in Antarctica by Solomon et al. (1987) from a ground-based station. Since then, other measurements have been performed by using ground-based (Miller et al., 1999), balloon-borne (Canty et al., 2005; Pommereau and Piquard, 1994; Renard et al., 1997; Riviere et al., 2003) or satellite measurements (Krecl et al., 2006; Wagner et al., 2002). However, the measurements performed using ground-based instruments do not allow the retrieval of vertical distributions. Furthermore, like balloon-borne measurements, they are localised and do not give a global coverage. Some of these satellite instruments used a nadir geometry to retrieve the total vertical column densities of OClO: this is the case for Global Ozone Monitoring Experiment (GOME) on ERS-2 (Burrows et al., 1999), SCanning Imaging Absorption spectroMeter for Atmospheric CHartographY (SCIAMACHY) onboard ENVISAT (Bovensmann et al., 1999) and Ozone Monitoring Instrument (OMI) on EOS-Aura (Levelt et al., 2006). The instrument Optical Spectrograph and InfraRed Imager System (OSIRIS) onboard the Odin satellite (Llewellyn et al., 2004) uses the limb scattering technique to retrieve vertical profiles of concentrations of $\mathrm{OClO}$ (Krecl et al., 2006). Moreover, SCIAMACHY has a limb-viewing mode and can also retrieve such vertical profiles. All these satellite perform daytime measurements. However, no results have been published for the moment. Note that the Stratospheric Aerosol and Gas Experiment III (SAGE III) on the Meteor-3M satellite (McCormick et al., 1991) could also perform lunar occultations and limb-scatter measurements in order to retrieve $\mathrm{OClO}$ vertical distributions but, for the moment, no results concerning this have been published. The Global Ozone Monitoring by Occultation of Stars (GOMOS) instrument on ENVISAT (see e.g., Bertaux et al., 1991; Kyrölä et al., 2004) is designed to retrieve the vertical concentrations of trace gases, including nighttime OClO. The stellar occultation technique used by GOMOS allows the measurements of $\mathrm{OClO}$ during nighttime. GOMOS is the only satellite instrument able to perform such nighttime measurements in the stratosphere. Preliminary results for the year 2003 have suggested the presence of a maximum in the $\mathrm{OClO}$ concentration in the equatorial upper stratosphere (Fussen et al., 2006). For the moment, the OClO product obtained from the GOMOS spectra has not been validated with data from other instruments. Even if these OClO measurements are not validated, this article highlights the capabilities of GOMOS to ensure a global monitoring of $\mathrm{OClO}$ and $\mathrm{NO}_{2}$ during nighttime.

We report in this paper the distributions of $\mathrm{OClO}, \mathrm{NO}_{2}$ and $\mathrm{O}_{3}$ slant column densities (SCD) retrieved from GOMOS measurements during the Arctic winters from 2003 to 2008 . After a brief summary of the GOMOS instrument, the retrieval algorithm is described. Then, we present the spatial distributions of $\mathrm{OClO}, \mathrm{NO}_{2}$ and $\mathrm{O}_{3}$ measured in the Arctic region in January 2008. Finally, we analyze time series of these species in the Arctic regions for the winter 2002/2003 to $2007 / 2008$.

\section{The GOMOS instrument}

GOMOS is one of the ten instruments onboard ESA's ENVISAT satellite launched on 1 March 2002 in a sunsynchronous orbit at an altitude of $800 \mathrm{~km}$. It is a stellar occultation spectrometer dedicated to the stratospheric and mesospheric remote sounding of the Earth. Operating in the UV, visible and NIR wavelength range (from 245 to $942 \mathrm{~nm}$ ), it allows the retrieval of vertical profiles of $\mathrm{O}_{3}, \mathrm{H}_{2} \mathrm{O}, \mathrm{NO}_{2}$, $\mathrm{NO}_{3}, \mathrm{O}_{2}$, aerosols and temperature. $\mathrm{OClO}$ is not a species retrieved systematically from the GOMOS operational algorithm because its slant optical thickness is small with respect to the instrumental signal-to-noise ratio. Nevertheless, a global determination of the stratospheric OClO distribution is possible if several GOMOS measurements are coadded (see Sect. 3 and Fussen et al., 2006). GOMOS is also equipped with two fast photometers used to correct for star scintillation and to retrieve temperature profiles.

GOMOS measures light from several stars that are setting behind the Earth horizon. The transmittance along the line of sight is obtained at each tangent altitude by dividing the stellar spectrum measured through the atmosphere by the reference stellar spectrum measured outside the atmosphere. This method is self-calibrated and offers the advantage of a large number of occultations per day (30 to 50 measurements per orbit compared to only 2 occultations for the solar occultation method). The wide variety of stars used combined with the sun-synchroneous orbit allows a global coverage in about 3 days. Nevertheless, the light intensity of stars is weak, influencing the signal-to-noise ratio of GOMOS measurements that depends on the star used.

\section{OClO retrieval}

The method used here to retrieve $\mathrm{OClO}$ is the same as those used by Fussen et al. (2006). We summarize below the main steps of this method. Due to the difficulties in the detection of OClO in a single GOMOS spectrum, we co-add transmittances (interpolated on a common altitude grid) in latitude bins of 10 degrees with a temporal resolution of one month. The transmittances used are already corrected for scintillation and dilution effects (Dalaudier et al., 2001). The consistency of each data set is checked by using statistical normality tests after which we calculate for each consistent bin a weighted median spectrum and the associated variances. A differential optical absorption spectroscopy (DOAS, Platt 
et al., 1979) technique is then applied to each weighted median spectrum in the [355-390 nm] wavelength region. In this spectral window, the main contributions to the total extinction are the molecular scattering, the aerosol extinction and the absorptions by $\mathrm{OClO}$ and $\mathrm{NO}_{2}$. Even though the ozone absorption in this wavelength range is weak, we take it into account in order to obtain a better accuracy for the retrieval. For the sake of an optimal signal-to-noise ratio, we use measurements from the star Sirius (Temperature $=11000 \mathrm{~K}$, Magnitude $=-1.44$ ) in this study.

The key principle of the DOAS method is to separate the total transmittances $T(\lambda)$ into two components, one varying slowly with the wavelength $\left(T_{S}(\lambda)\right)$ and the other rapidly varying (noted $d T(\lambda)$ and named experimental differential transmittance). The slowly varying transmittances are calculated using a second order polynomial. It corresponds to the molecular scattering, the aerosol extinction and the slowly varying components of the gaseous absorptions. In the same way, we separate the absorption cross sections $\left(\sigma_{i}\right)$ of each species into a slowly varying component (calculated also with a second order polynomial) and a high frequency component. The differential cross sections $\delta \sigma_{i}$ are then calculated as the differences between the absorption cross sections and the smoothed ones. Thus, the modelled differential transmittance $M(\lambda)$ can be written as:

$$
\begin{aligned}
& M(\lambda)=T_{S}\left(1-\exp \left[-\left(N_{\mathrm{O}_{3}} \delta \sigma_{O_{3}}+N_{\mathrm{NO}_{2}} \delta \sigma_{\mathrm{NO}_{2}}\right.\right.\right. \\
& \left.\left.\left.+N_{\mathrm{OClO}} \delta \sigma_{\mathrm{OClO}}\right)\right]\right)
\end{aligned}
$$

where $N_{i}$ are the slant column densities (SCD). The $N_{i}$ are then obtained by a nonlinear least-squares minimization of the difference between $M(\lambda)$ and $d T(\lambda)$ weighted by the experimental errors. In the minimization procedure, the wavelength is eventually shifted by $\Delta \lambda$. The estimated retrieval error is extracted from the jacobian. Note that the cross sections used in the retrieval are the same regardless of the temperature. The cross-sections used for ozone are provided by Orphal (2002), those for $\mathrm{NO}_{2}$ by Merienne et al. (1995) and those for OClO by Wahner et al. (1987).

Unfortunately, for the moment, no direct validation of the OClO SCD obtained can be achieved. In the future, a validation exercise will be done with the OSIRIS, SCIAMACHY, OMI and GOME results. Nonetheless, we can compare the $\mathrm{NO}_{2}$ SCD obtained from our DOAS procedure and from the GOMOS operational algorithm (European Space Agency (ESA), 2007). Figure 1 shows a typical comparison for August 2003 for the $\left[60-65^{\circ} \mathrm{S}\right]$ latitudinal band. The $\mathrm{NO}_{2}$ SCDs of each measurement in this bin, retrieved from the GOMOS operational algorithm are combined to obtain the weighted median SCD observed in the left panel (dashed line). The relative differences between these two profiles are mostly lower than $10 \%$ (in absolute value) and this result holds for the other latitudinal bands. We can therefore conclude that the $\mathrm{NO}_{2} \mathrm{SCDs}$ retrieved from both algo-
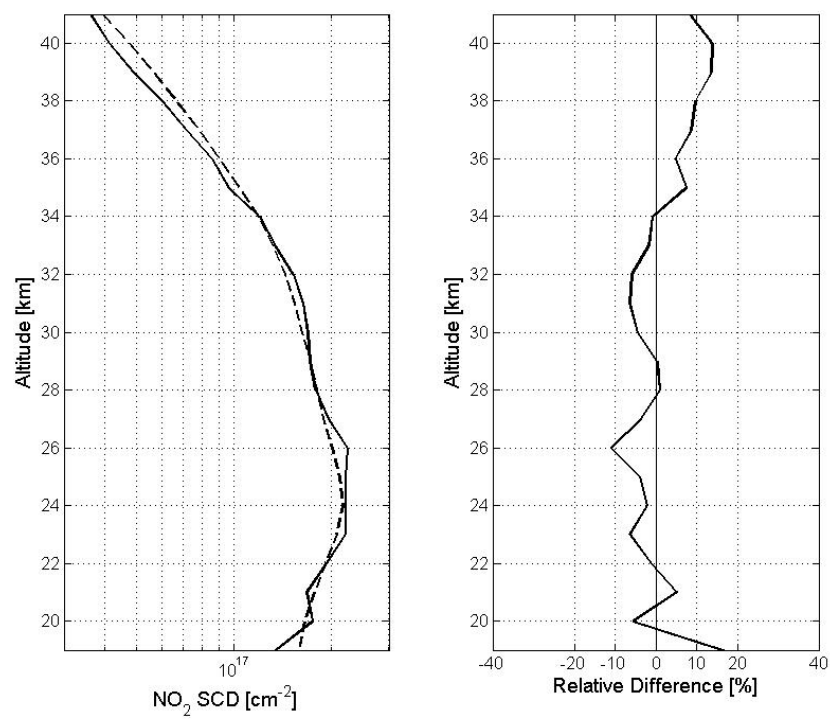

Fig. 1. On the left: vertical profiles of $\mathrm{NO}_{2}$ slant column densities for August 2003 in the $\left[60^{\circ}-65^{\circ} \mathrm{S}\right]$ latitudinal band. The dashed line corresponds to the profile retrieved from the GOMOS operational algorithm and the solid line to the profile retrieved in this study. On the right: vertical profile of the relative differences.

rithms are consistent and that our DOAS algorithm works well. Furthermore, in a previous article, Fussen et al. (2006) shows a comparisons between $\mathrm{OClO}$ obtained from GOMOS measurements and calculated from the Belgian Assimilation System of Chemical Observations of ENVISAT (BASCOE) model (Errera and Fonteyn, 2001) for the year 2003. A good agreement results from this comparison. Thus, we can be confident with the OClO product obtained from the DOAS approach used in this study.

\section{Spatial distribution of $\mathrm{OClO}, \mathrm{NO}_{2}$ and $\mathrm{O}_{3}$ in the Arc- tic vortex in January 2008}

According to Kuttippurath et al. (2009), the stratosphere in the winter 2007/2008 was very cold. The temperature started to decrease in November and remained low until a major stratospheric warming in late February. Inside the polar vortex, the temperatures were below the PSC temperature threshold until the end of February. Indeed, PSCs were observed from different Arctic stations, a possible sign of a strong chlorine activation.

In January 2008, the polar vortex was not centered on the geographical north pole. It gradually moved towards Europe. Figure 2 shows a potential vorticity map obtained from the MIMOSA model (Hauchecorne et al., 2002) at $675 \mathrm{~K}$ (about $27 \mathrm{~km}$ ) on 10 January 2008. It highlights that the polar vortex extends from the North pole down to $60^{\circ} \mathrm{N}$ latitudes above the regions whose longitude lies between $70^{\circ} \mathrm{W}$ and $135^{\circ} \mathrm{E}$. 


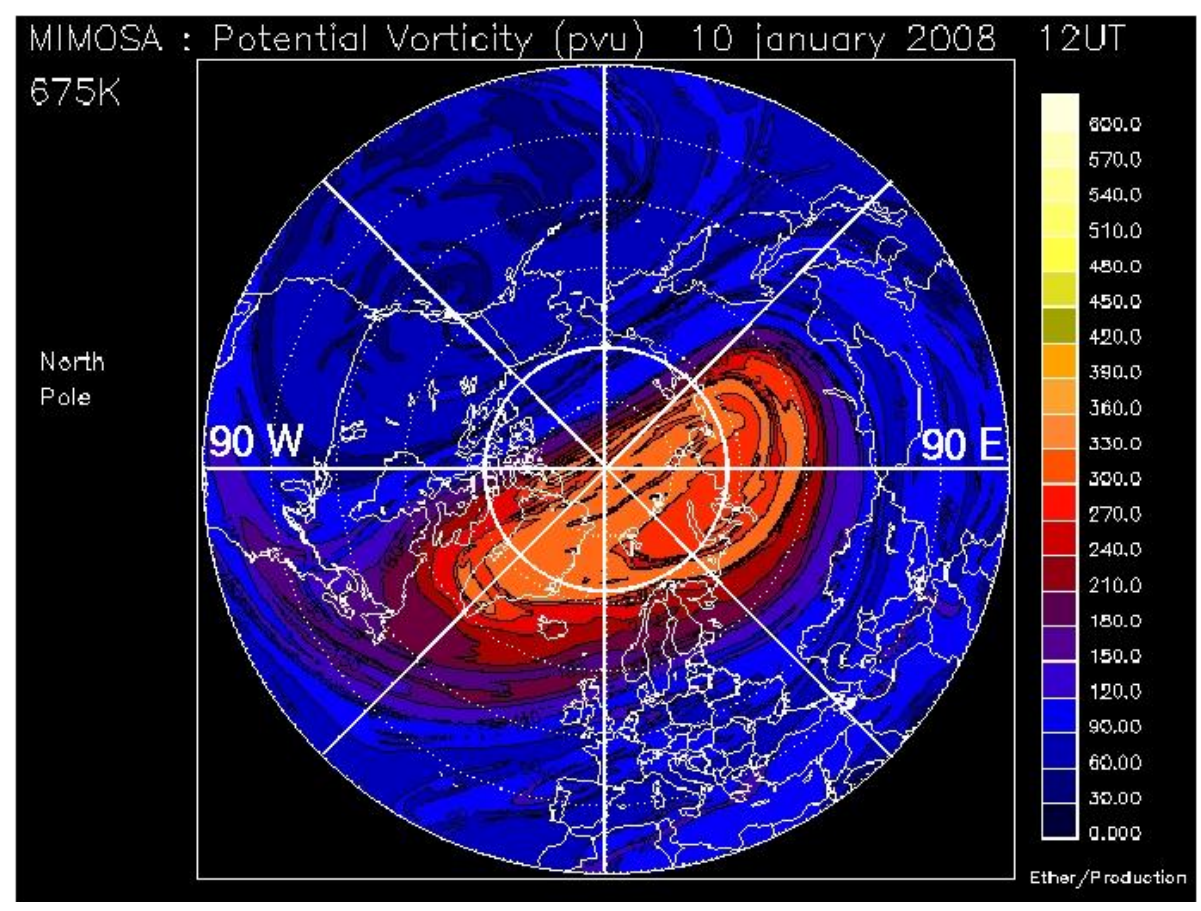

Fig. 2. Potential vorticity map calculated by the MIMOSA high-resolution advection model at 12:00 UT on 10 January 2008 at $675 \mathrm{~K}$ (about $27 \mathrm{~km}$ ). The white circle at $72^{\circ} \mathrm{N}$ represents the geolocation of the tangent points of the GOMOS Sirius occultations in January 2008.

Consequently, a 5 degree latitudinal band in the northern hemisphere was not homogeneous for the highest latitude. In January 2008, only the latitudinal band near $72^{\circ}$ was sounded by GOMOS (Sirius occultations). In Fig. 2, the white circle represents the spatial distribution of these GOMOS Sirius occultations. They are distributed along the entire longitudinal range: some of them were performed inside the polar vortex and the others outside. Hence, we cannot bin together all these measurements. Figure 3 shows that the distribution of the transmittances at $385 \mathrm{~nm}$ and at $30 \mathrm{~km}$ for the GOMOS measurements in this latitudinal band are bimodal. Note that for other altitudes and wavelengths, this bimodality of the transmittances is also observed. One expects that high transmittances correspond to measurements inside the polar vortex. Indeed, because of the denoxification of the polar vortex, the $\mathrm{NO}_{2}$ absorption is weak.

To take into account the specificity of the position of the polar vortex in January 2008, we have divided the latitudinal band into $10^{\circ}$ longitudinal boxes. In each box, we check the consistency of the measurements (statistical test) and we calculate the weighted median transmittance spectra. Then, we use the DOAS technique to retrieve $\mathrm{OClO}, \mathrm{NO}_{2}$ and $\mathrm{O}_{3}$ $\mathrm{SCD}$ in each box. The results concerning $\mathrm{OClO}$ are presented in Fig. 4. It represents the longitudinal variations of OClO SCD for three different altitudes: 17, 24 and $29 \mathrm{~km}$. It appears clearly that maxima of OCIO SCD occur in the activated polar vortex (between $70^{\circ} \mathrm{W}$ and $135^{\circ} \mathrm{E}$ ) at the two lowest altitudes. At $29 \mathrm{~km}$, the shape of the distribution is

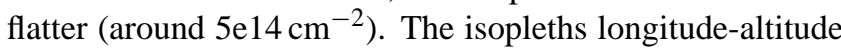
for $\mathrm{OClO}, \mathrm{NO}_{2}, \mathrm{O}_{3} \mathrm{SCDs}$ and for the temperature provided by the European Center for Medium-Range Weather Forecasts (ECMWF) are presented in Fig. 5. The $\mathrm{NO}_{2}$ and $\mathrm{O}_{3}$ SCDs represented in this Figure are from the operational algorithm. The activated vortex region is marked by a strong OClO SCD in the lower stratosphere and by low $\mathrm{NO}_{2}$ SCDs. This is in a good agreement with our current knowledge of stratospheric chemistry (Brasseur and Solomon, 2005). According to Sessler et al. (1995), OClO presence is an indicator of halogen activation. The presence of $\mathrm{ClO}$ in the lower stratosphere in the polar vortex is confirmed by the instrument Microwave Limb Sounder (MLS) instrument onboard EOS Aura (Earth Observing System, Schoeberl et al., 2006): in Fig. 6, a maximum of $\mathrm{ClO}$ volume mixing ratio in the lower stratosphere is located in the Arctic polar vortex (at high equivalent latitude, Santee et al., 2008). Figure 5 shows also the longitudinal and vertical distribution of ozone SCD. It shows a slow decreasing of ozone inside the polar vortex. This is in a good agreement with the halogen activation and with the denoxification observed. Nonetheless, the role of dynamics in this observing ozone decreasing can not be highlighted by our study. One may also notice the low temperatures (lower than $200 \mathrm{~K}$ ) encountered in the areas where the halogen activation and the denoxification are observed, a condition for the presence of PSCs. 


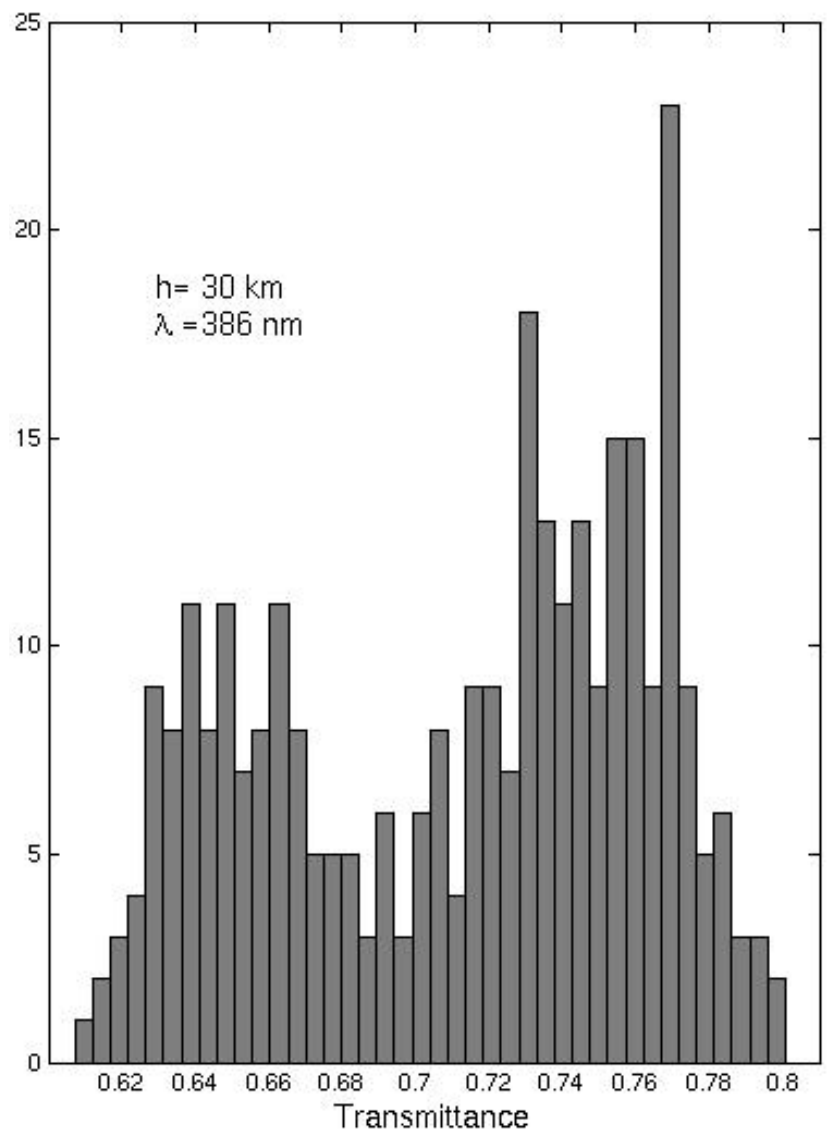

Fig. 3. Histogram of transmittances at $30 \mathrm{~km}$ and at $386 \mathrm{~nm}$ from the GOMOS Sirius occultations in January 2008 in the $70-75^{\circ} \mathrm{N}$ latitudinal range.

\section{Temporal evolution of $\mathrm{OClO}, \mathrm{NO}_{2}$ and $\mathrm{O}_{3}$ in Arctic winters}

In this section, we study the temporal evolution of the OClO, $\mathrm{NO}_{2}$ and $\mathrm{O}_{3}$ SCDs in the Arctic regions during winter from $2002 / 2003$ to 2007/2008. Figure 7 shows the geolocation of the Sirius occultations in the northern hemisphere (latitude greater than $65^{\circ}$ ). All these measurements occurred during polar nights. This study was performed with a temporal resolution of two days. Bins with less than 4 measurements are not considered as statistically significant and are not taken into account. This restriction eliminates only 11 bins among a total of 200 bins. The same method is then applied on each set: the weighted median is calculated and the DOAS retrieval is applied. Thus, we retrieve the OClO SCD, the $\mathrm{NO}_{2}$ SCD and the $\mathrm{O}_{3}$ SCD as a function of time in the Arctic winter. Note that, for this study, we do not take into account the position of measurements relative to the polar vortex. In other terms, no longitudinal separation (like in the previous section) has been done because the number of measurements available is not sufficient to perform spatio-temporal binning
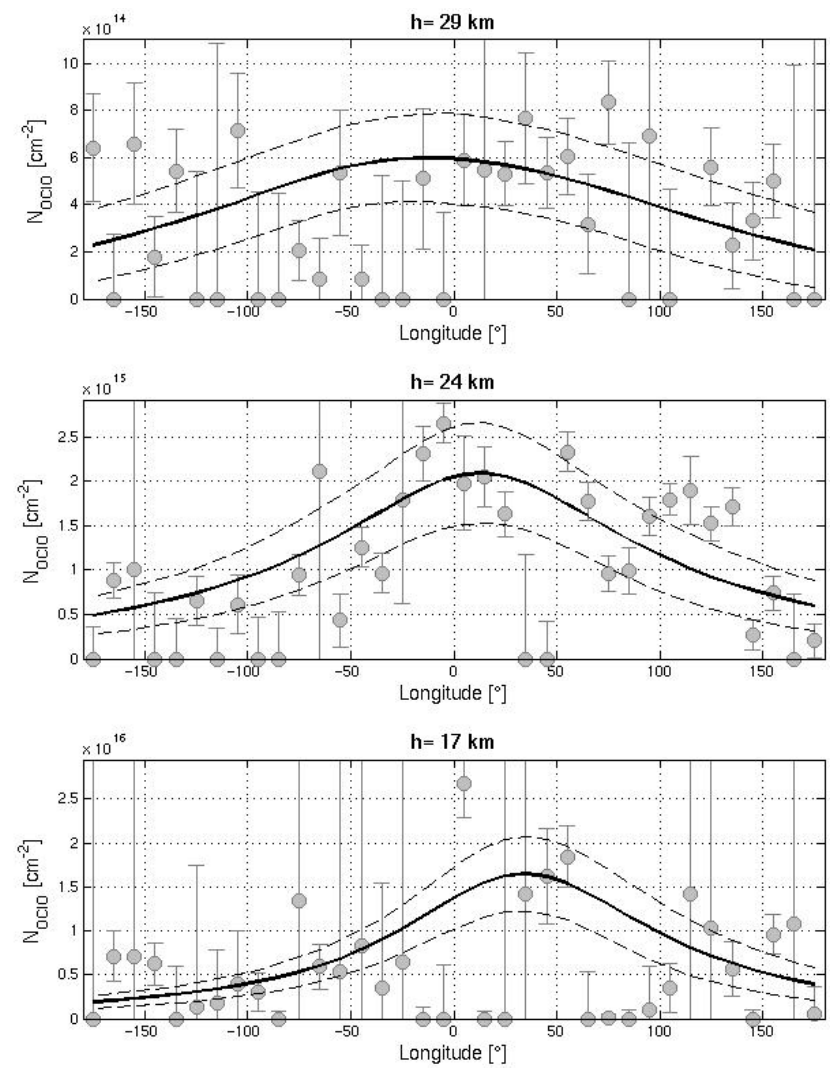

Fig. 4. OClO slant column densities as a function of longitude with the spectral inversion error bars for January 2008 in the Arctic polar region. The solid line is the result of an error-weighted fit by a simple lorentzian function. The dashed lines represent the associated confidence interval at $1-\sigma$.

with a two day resolution. One should keep in mind that this can cause the averaging of inconsistent GOMOS measurements (like for the winter 2007/2008, cf. Sect. 4) introducing some uncertainty in our temporal study.

Figure 8 shows the minimum temperature reached in the stratosphere (panels A) and the $\mathrm{O}_{3}$ (panels $\mathrm{B}$ ), $\mathrm{NO}_{2}$ (panels C) and $\mathrm{OClO}$ (panels D) SCDs (with the error bars) at the altitude of $19 \mathrm{~km}$ as a function of time. This level has been chosen because at this altitude both denoxification and halogen activation are clearly observable. The winter 2006/2007 was not studied due to the lack of data. In the next paragraphs, we will describe the results obtained for each winter.

\subsection{The Arctic winter 2002/2003}

During this winter, stratospheric minimum temperatures retrieved using the GOMOS photometers were below the temperature of formation of PSC from mid November to mid January (panel A). Then, temperatures were higher after mid January, almost always above $T_{\mathrm{PSC}}$. Consequently, the halogen activation must be more important during this cold 

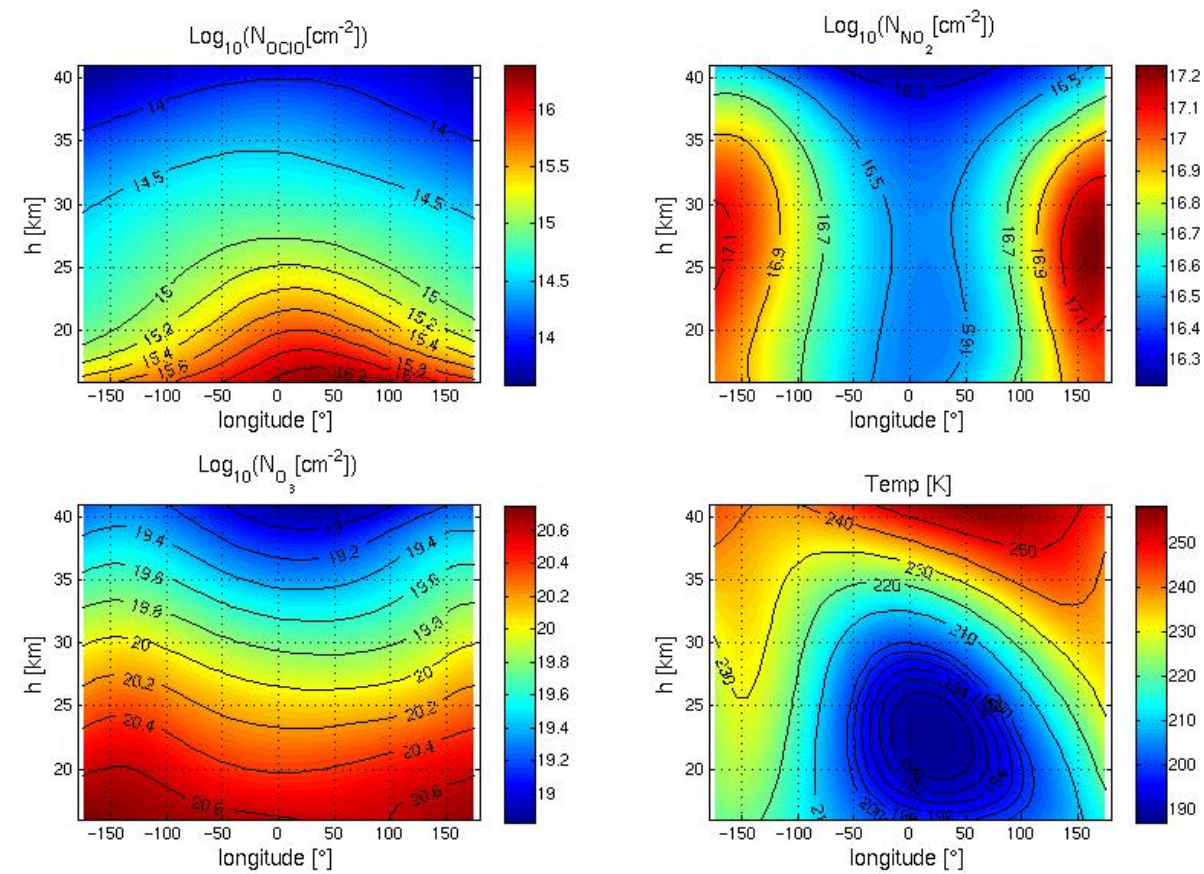

Fig. 5. Isopleths (longitude-altitude) of the OClO SCD retrieved from the DOAS procedure, $\mathrm{NO}_{2}$ and $\mathrm{O}_{3} \mathrm{SCDs}$ retrieved from the operational algorithm, and the temperature provided by the ECMWF in January 2008 in the $70-75^{\circ} \mathrm{N}$ latitudinal range.

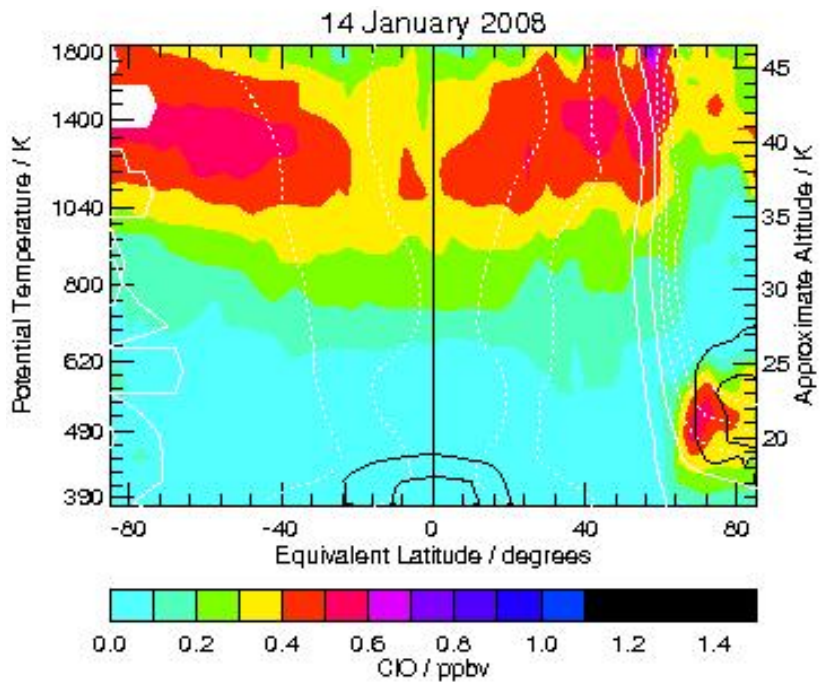

Fig. 6. Isopleth (equivalent latitude-altitude) of the $\mathrm{ClO}$ volume mixing ratios on January 2008 from MLS measurements (courtesy of G. Manney). The white lines represent iso-PV and the black lines represent iso-temperature from 180 to $200 \mathrm{~K}$ with a $5 \mathrm{~K}$ increment (from GEOS-5).

period: we observed a slow increase of OClO SCDs all along this period (reaching $2.0 \mathrm{e} 15 \mathrm{~cm}^{-2}$ at the end of December) and then, after mid January, OClO SCDs began to decrease

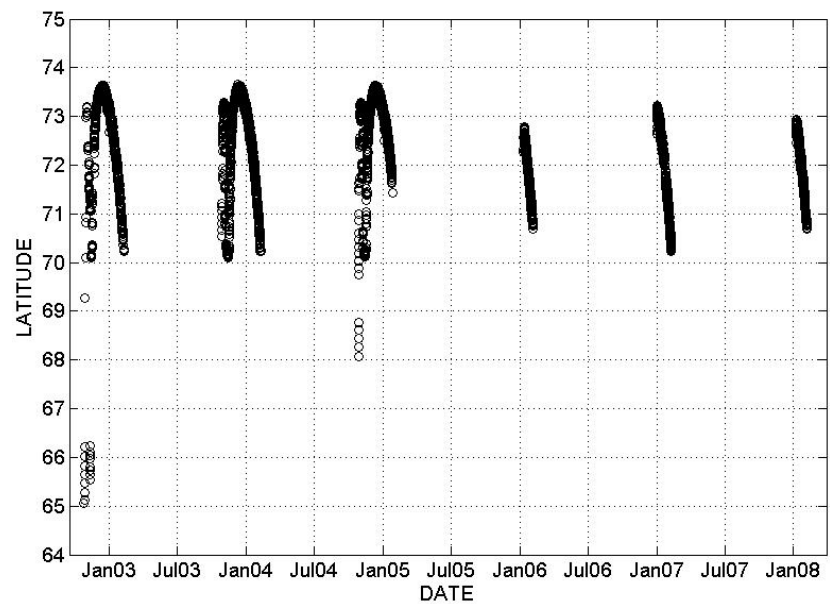

Fig. 7. Geolocation of the tangent points of all the GOMOS Sirius occultations above $65^{\circ} \mathrm{N}$ between September 2002 and May 2008.

slightly. For $\mathrm{NO}_{2}$, it is the reverse: we observed a decrease of the $\mathrm{NO}_{2} \mathrm{SCDs}$ during the cold period and then an increase. Concerning ozone, the SCDs are very noisy. This is mainly because ozone is a weak absorber in the wavelength region used in the retrieval. 

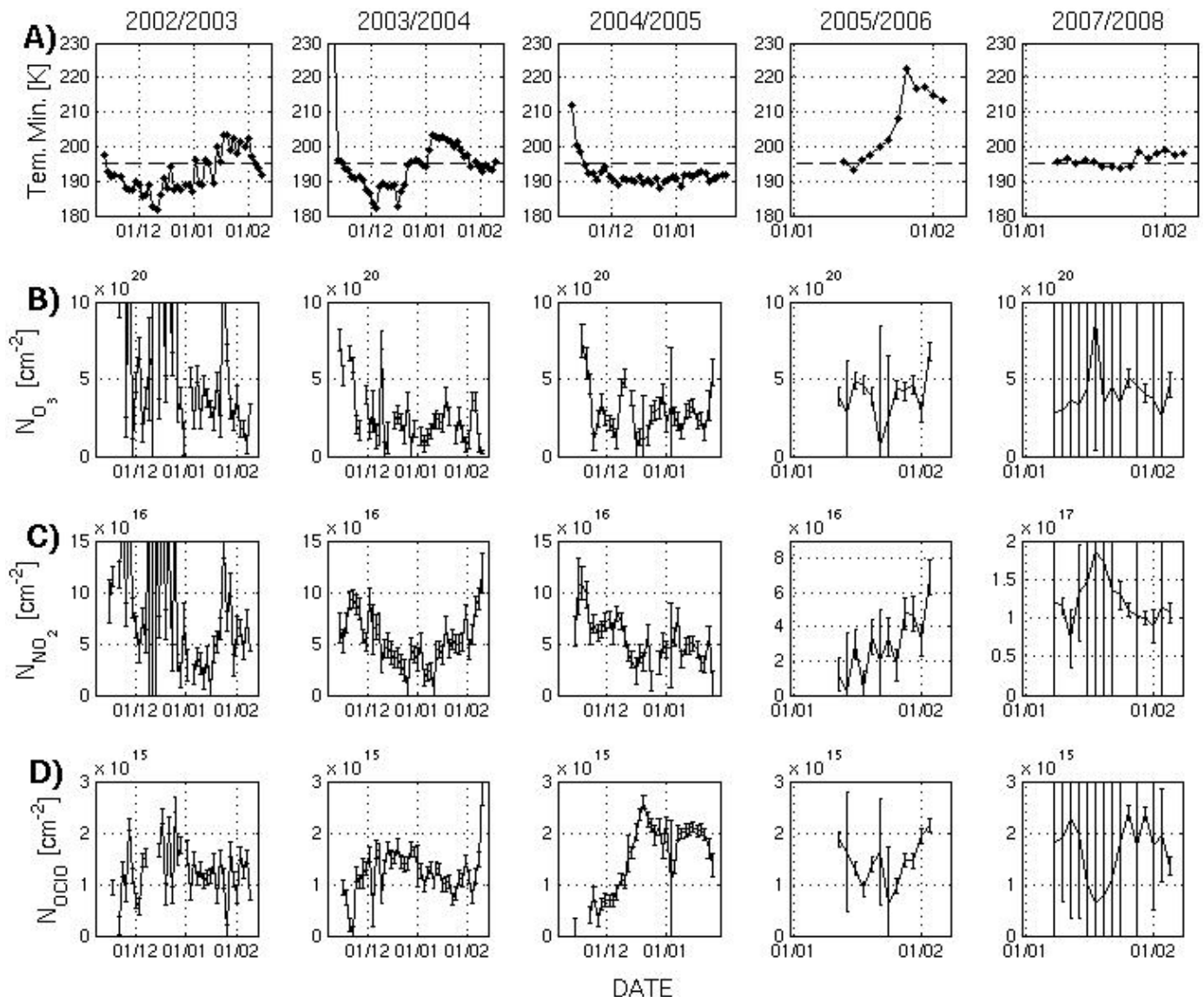

Fig. 8. Time series of the winters 2002/2003 to 2007/2008 (except 2006/2007) of the minimal temperature in the stratosphere (A) and of $\mathrm{O}_{3}(\mathbf{B}), \mathrm{NO}_{2}(\mathbf{C})$ and OClO SCDs (D) at $19 \mathrm{~km}$ with the spectral inversion error bars, all retrieved from GOMOS measurements at the geolocations of Fig. 7. The dashed lines on the figures (A) correspond to $\mathrm{T}_{\mathrm{PSC}}$.

\subsection{The Arctic winter 2003/2004}

This winter is also characterized by two periods: a cold one (from mid November to late December when the minimum temperatures are below $T_{\mathrm{PSC}}$ ) followed by a warming. During the cold period, OClO SCDs are increasing, $\mathrm{NO}_{2}$ and $\mathrm{O}_{3}$ SCDs are both decreasing. When the temperatures gets higher, $\mathrm{NO}_{2}$ SCDs are increasing and OClO SCDs are decreasing. However, ozone SCDs remain approximately constant. For this winter, a strong contrast (for $\mathrm{OClO}$ and $\mathrm{NO}_{2}$ SCDs) is observed between the cold and the warm period. For this winter the period of high halogen activation corresponds to the period with the highest denoxification. This is in a good agreement with our current knowledge in stratospheric chemistry.

\subsection{The Arctic winter 2004/2005}

According to Kleinböhl et al. (2005), the temperatures in the stratosphere were the lowest since 50 years. They remained below $T_{\mathrm{PSC}}$ from late November to late February.
Consequently, lots of PSCs have been observed during the entire winter. The minimum GOMOS temperatures are in agreement with this situation. They are below $T_{\mathrm{PSC}}$ from late November to late January. OClO SCDs strongly increased fom late November to mid December, reaching approximately $2.5 \mathrm{e} 15 \mathrm{~cm}^{-2}$. In the same time, $\mathrm{NO}_{2} \mathrm{SCDs}$ decreased strongly. From mid December, $\mathrm{OClO}$ and $\mathrm{NO}_{2}$ remained roughly constant. Ozone SCDs are weak all along this period. During this exceptionally cold and stable winter, GOMOS has observed strong and long halogen activation and denoxification.

\subsection{The Arctic winter 2005/2006}

For this winter, GOMOS has recorded measurements only during January. The minimum temperatures retrieved from the GOMOS photometers are not very low. They are below $T_{\mathrm{PSC}}$ only for a few days in mid January (during the GOMOS measurements period). Then the miminum temperatures in the stratosphere increased. Consequently, we observed an increase of the $\mathrm{NO}_{2} \mathrm{SCDs}$ (from $2.5 \mathrm{e} 15 \mathrm{~cm}^{-2}$ in mid January 
to $6 \mathrm{e} 16 \mathrm{~cm}^{-2}$ in early February). Nevertheless, we cannot observe a diminution of the OClO SCDs as expected. For an unclear reason, the temporal evolution of OClO SCDs is first decreasing and then increasing. Concerning ozone, nothing can be deduced by studying the temporal evolution.

\subsection{The Arctic winter 2007/2008}

The GOMOS measurements for this winter occurred only in January 2008. The minimum temperatures are often equal to $T_{\mathrm{PSC}}$ during the whole GOMOS measurement period. Nevertheless, we can distinguish neither denoxification nor halogen activation. This is probably because no longitudinal discrimination is carried out for this temporal study. Indeed, the polar vortex is not centered on the geographical pole and the latitudinal band sounded by the GOMOS measurements is not homogeneous (cf. Sect. 4). This lack of homogeneity of the GOMOS measurements used generates the large error bars observed on the $\mathrm{O}_{3}, \mathrm{NO}_{2}$ and OClO SCDs. However, we can observe an anticorrelation between $\mathrm{NO}_{2}$ and $\mathrm{OClO}$ SCDs: in mid January a sudden increase of $\mathrm{NO}_{2} \mathrm{SCD}$ occurred at the same time as a sudden decrease of the OClO $\mathrm{SCD}$. This is followed by a decrease of $\mathrm{NO}_{2}$ and an increase of OClO SCD. This anticorrelation is in agreement with our current knowledge in the stratospheric chemistry. We can not discuss more this observed anticorrelation because of the large error bars.

\section{Conclusions}

This preliminary work focuses on the interactions between $\mathrm{NO}_{2}, \mathrm{O}_{3}$ and $\mathrm{OClO}$ in the Arctic polar vortex. The slant column densities of these species are retrieved during nighttime from Sirius occultations as observed by the GOMOS instrument. First, the longitudinal distributions of these species in January 2008 highlight strong variations of $\mathrm{OClO}$ and $\mathrm{NO}_{2}$ (as a function of the longitude) in the lower stratosphere: in the polar vortex, weak $\mathrm{NO}_{2} \mathrm{SCD}$ and strong OClO SCD are observed, and the reverse situation outside the polar vortex. Halogen activation (marked by high OClO SCDs) and denoxification which occurs in the polar vortex are clearly detectable. Hence, the GOMOS spectrometer appears to be a suitable instrument to perform a monitoring of such important species in the polar vortex. Furthermore, the temporal study confirms that the halogen activation degree and the concomitant denoxification can be effectively monitored by GOMOS. We were able to highlight the correlation between cold temperatures (below $T_{\mathrm{PSC}}$ ), weak $\mathrm{NO}_{2} \mathrm{SCDs}$ and strong OClO SCDs inside the Arctic polar vortex for several winters. It is important to continue the monitoring of these species to better understand the interactions between halogen and nitrogen species within the framework of the ozone depletion. This paper reports the first study of OClO distri- bution using limb-viewing satellite measurements performed during night in the Arctic regions.

The next step in the use of the GOMOS measurements for the OClO retrieval is to validate this product. The accuracy and reliability of our OClO products will be established through comparison with other measurements made by other instruments. For this aim, we need correlative measurements from other satellite instruments (like OSIRIS, SCIAMACHY, GOME or OMI). Nevertheless, these instruments perform daytime measurements so it will be necessary to model the diurnal variations of OClO. Direct comparisons will be possible only with the profiles retrieved from the SALOMON (Spectroscopie d'Absorption Lunaire pour l'Observation des Minoritaires et $\mathrm{NO}_{\mathrm{x}}$, Renard et al., 1997) balloon-borne instrument (lunar occultation method). In a forthcoming work, we will build a global OClO climatology.

Acknowledgements. This study was funded by the PRODEX 9 contract SECPEA under the authority of the Belgian Space Science Office (BELSPO).

We thank the MLS science team for giving us the authorization to use the $\mathrm{ClO}$ figure.

Edited by: P. Bernath

\section{References}

Bertaux, J. L., Mégie, G., Widemann, T., Chassefière, E., Pellinen, R., Kyrölä, E., Korpela, S., and Simon, P.: Monitoring of ozone trend by stellar occultations: the GOMOS instrument, Adv. Space Res., 11, 237-242, doi:10.1016/0273-1177(91)90426-K, 1991.

Bovensmann, H., Burrows, J. P., Buchwitz, M., Frerick, J., Noël, S., Rozanov, V. V., Chance, K. V., and Goede, A. P. H.: SCIAMACHY: Mission Objectives and Measurement Modes, J. Atmos. Sci., 56, 127-150, doi:10.1175/1520-0469(1999)056, 1999.

Brasseur, G. P. and Solomon, S.: Aeronomy of the Middle Atmosphere: Chemistry and Physics of the Stratosphere and Mesosphere, Springer, Berlin, 2005.

Burrows, J. P., Weber, M., Buchwitz, M., Rozanov, V., LadstätterWeißenmayer, A., Richter, A., Debeek, R., Hoogen, R., Bramstedt, K., Eichmann, K.-U., Eisinger, M., and Perner, D.: The Global Ozone Monitoring Experiment (GOME): Mission Concept and First Scientific Results., J. Atmos. Sci., 56, 151-175, doi:10.1175/1520-0469(1999)056, 1999.

Canty, T., Riviere, E. D., Salawitch, R. J., Berthet, G., Renard, J. B., Pfeilsticker, K., Dorf, M., Butz, A., Bösch, H., Stimpfle, R. M., Wilmouth, D. M., Richard, E. C., Fahey, D. W., Popp, P. J., Schoeberl, M. R., Lait, L. R., and Bui, T. P.: Nighttime OClO in the winter Arctic vortex, J. Geophys. Res., 110, D01301, doi:10.1029/2004JD005035, 2005.

Dalaudier, F., Kan, V., and Gurvich, A. S.: Chromatic Refraction with Global Ozone Monitoring by Occultation of Stars. I. Description and Scintillation Correction, Appl. Opt., 40, 866-877, doi:10.1364/AO.40.000866, 2001.

Errera, Q. and Fonteyn, D.: Four-dimensional variational chemical assimilation of CRISTA stratospheric measurements, J. 
Geophys. Res., 106, 12253-12266, doi:10.1029/2001JD900010, 2001.

European Space Agency (ESA): GOMOS Algorithm Theoretical Basis Document version 2.0, technical report, available at: http: //envisat.esa.int/instruments/gomos/atbd/, 2007.

Farman, J. C., Gardiner, G., and Shanklin, J. D.: Large losses of total ozone in antartica reveal seasonal $\mathrm{ClO}_{\mathrm{x}} / \mathrm{NO}_{\mathrm{x}}$ interaction, Nature, 315, 207-210, 1985.

Fussen, D., Vanhellemont, F., Dodion, J., Bingen, C., Mateshvili, N., Daerden, F., Fonteyn, D., Errera, Q., Chabrillat, S., Kyrölä, E., Tamminen, J., Sofieva, V., Hauchecorne, A., Dalaudier, F., Bertaux, J.-L., Renard, J.-B., Fraisse, R., d'Andon, O. F., Barrot, G., Guirlet, M., Mangin, A., Fehr, T., Snoeij, P., and Saavedra, L.: A global OClO stratospheric layer discovered in GOMOS stellar occultation measurements, Geophys. Res. Lett., 33, L13815, doi:10.1029/2006GL026406, 2006.

Hauchecorne, A., Godin, S., Marchand, M., Hesse, B., and Souprayen, C.: Quantification of the transport of chemical constituents from the polar vortex to midlatitudes in the lower stratosphere using the high resolution advection model MIMOSA and effective diffusivity, J. Geophys. Res., 107(D20), 8289, doi:10.1029/2001JD00049, 2002.

Kleinböhl, A., Bremer, H., Küllmann, H., Kuttippurah, J., Browell, E. V., Canty, T., Salawitch, R. J., Toon, G. L., and Nothol, J.: Denitrification in the Arctic mid-winter 2004/2005 observed by airborne submillimeter radiometry, Geophys. Res. Lett., 32, 19811-19814, doi:10.1029/2005GL02408, 2005.

Krecl, P., Haley, C. S., Stegman, J., Brohede, S. M., and Berthet, G.: Retrieving the vertical distribution of stratospheric $\mathrm{OClO}$ from Odin/OSIRIS limb-scattered sunlight measurements, Atmos. Chem. Phys., 6, 1879-1894, 2006, http://www.atmos-chem-phys.net/6/1879/2006/.

Kuttippurath, J., Godin-Beekmann, S., Lefèvre, F., Pazmiño, A.: Ozone depletion in the Arctic winter 2007-2008, Int. J. Remote Sens., 30, 15, 4071-4082, 2009.

Kyrölä, E., Tamminen, J., Leppelmeier, G. W., Sofieva, V., Hassinen, S., Bertaux, J. L., Hauchecorne, A., Dalaudier, F., Cot, C., Korablev, O., Fanton D'Andon, O., Barrot, G., Mangin, A., Théodore, B., Guirlet, M., Etanchaud, F., Snoeij, P., Koopman, R., Saavedra, L., Fraisse, R., Fussen, D., and Vanhellemont, F.: GOMOS on Envisat: an overview, Adv. Space Res., 33, 10201028, doi:10.1016/S0273-1177(03)00590-8, 2004.

Levelt, P. F., van den Oord, G. H. J., Dobber, M. R., Malkki, A., Visser, H., de Vries, J., Stammes, P., Lundell, J. O. V., and Saari, H.: The Ozone Monitoring Instrument, IEEE T. Geosci. Remote Sens., 44, 1093-1101, doi:10.1109/TGRS.2006.872333, 2006.

Llewellyn, E., Lloyd, N. D., Degenstein, D. A., Gattinger, R. L., Petelina, S. V., Bourassa, A. E., Wiensz, J. T., Ivanov, E. V., McDade, I. C., Solheim, B. H., McConnell, J. C., Haley, C. S., von Savigny, C., Sioris, C. E., McLinden, C. A., Griffioen, E., Kaminski, J., Evans, W. F. J., Puckrin, E., Strong, K., Wehrle, V., Hum, R. H., Kendall, D. J. W., Matsushita, J., Murtagh, D. P., Brohede, S., Stegman, J., Witt, G., Barnes, G., Payne, W. F., Piche, L., Smith, K., Warshaw, G., Deslauniers, D. L., Marchand, P., Richardson, E. H., King, R. A., Wevers, I., McCreath, W., Kyrola, E., Oikarinen, L., Leppelmeier, G. W., Auvinen, H., Megie, G., Hauchecorne, A., Lefevre, F., de La Noe, J., Ricaud, P., Frisk, U., Sjoberg, F., von Scheele, F., and Nordh, L.: The OSIRIS instrument on the Odin spacecraft, Can. J. Phys., 82,
411-422, doi:10.1139/p04-005, 2004.

McCormick, M. P., Chu, W. P., Zawodny, J. M., Mauldin, L. E., and McMaster, L. R.: Stratospheric aerosol and gas experiment III (SAGE III) aerosol and trace gas measurements for Earth Observing System (EOS), in: Society of Photo-Optical Instrumentation Engineers (SPIE) Conference Series, 125-141, 1991.

Merienne, M. F., Jenouvrier, A., and Coquart, B.: The $\mathrm{NO}_{2}$ absorption spectrum: absorption cross-sections at ambient temperature in the 300-500 nm region, J. Atmos. Chem., 20, 281-297, 1995.

Miller, H. L. J., Sanders, R. W., and Solomon, S.: Observations and interpretation of column OClO seasonal cycles at two polar sites, J. Geophys. Res., 104, 18769-18783, 1999.

Orphal, J.: A Critical Review of the Absorption Cross-Sections of $\mathrm{O}_{3}$ and $\mathrm{NO}_{2}$ in the $240-790 \mathrm{~nm}$ Region. Part I: Ozone, ESA Technical Note MO-TN-ESA-GO-0302, 2002.

Platt, U., Perner, D., and Pätz, H. W.: Simultaneous measurement of atmospheric $\mathrm{CH}_{2} \mathrm{O}, \mathrm{O}_{3}$, and $\mathrm{NO}_{2}$ by differential optical absorption, J. Geophys. Res., 84, 6329-6335, doi:10.1029/ JC084iC10p06329, 1979.

Pommereau, J.-P. and Piquard, J.: Observations of the vertical distribution of stratospheric OClO, Geophys. Res. Lett., 21, 12311234, doi:10.1029/94GL00390, 1994.

Renard, J. B., Lefevre, F., Pirre, M., Robert, C., and Huguenin, D.: Vertical profile of night-time stratospheric OClO, J. Atmos. Chem., 26, 65-76, 1997.

Renard, J. B., Chartrier, M., Robert, C., Chalumeau, G., Berthet, G., Pirre, M., Pommerreau, J. P., Goutail, F.: SALOMON: a new, light balloonborne UV-visible spectrometer for nighttime observations of stratospheric trace gas species, Appl. Opt., 39, 386-392, 2000.

Riviere, E. D., Pirre, M., Berthet, G., Renard, J. B., Taupin, F. G., Huret, N., and Chartier, M.: On the interaction between nitrogen and halogen species in the Arctic polar vortex during THESEO and THESEO 2000, J. Geophys. Res., 108, 8311, doi:10.1029/ 2002JD002087, 2003.

Santee, M. L., Lambert, A., Read, W. G., Livesey, N. J., Manney, G. L., Cofielfd, R. E., Cuddy, D. T., Daffer, W. H., Drouin, D. J. an d Froidevaux, L., Fuller, R. A., Jarnot, R. A., Knosp, B. W., Perun, V. S., Snyder, W. V., Stek, P. C., Thurstans, R. P., Wagner, P. A., Waters, J. W., Connor, B., Urban, J., Murtagh, D., Ricaud, P., Barrett, B., Kleinboehl, A., Kuttippurath, J., Kullmann, H., von Hobe, M., Toon, G. C., and Stachnik, R. A.: Validation of the Aura Microwave Limb Sounder ClO Measurements, J. Geophys. Res., 113, D15S22, doi:10.1029/2007JD008762, 2008.

Schoeberl, M. R., Douglass, A. R., Hilsenrath, E., Bhartia, P. K., Beer, R., Waters, J. W., Gunson, M. R., Froidevaux, L., Gille, J. C., Barnett, J. J., Levelt, P. F., and de Cola, P.: Overview of the EOS Aura Mission, IEEE T. Geosci. Remote Sens., 44, 10661074, doi:10.1109/TGRS.2005.861950, 2006.

Sessler, J., Chipperfield, M. P., Pyle, J. A., and Toumi, R.: Stratospheric OClO measurements as a poor quantitative indicator of chlorine activation, Geophys. Res. Lett., 22, 687-690, 1995.

Solomon, S.: Stratospheric ozone depletion: A review of concepts and history, Rev. Geophys., 37, 275-316, 1999.

Solomon, S., Garcia, R. R., Rowland, F. S., and Wuebbles, D. J.: On the depletion of antarctic ozone, Nature, 321, 755-758, 1986.

Solomon, S., Mount, G. H., and Sanders, R. W., and Schmeltekopf, A. L.: Visible spectroscopy at McMurdo station, Antartica 2. Observations of OClO, J. Geophys. Res., 92, 8329-8338, 1987. 
Wagner, T., Wittrock, F., Richter, A., Wenig, M., and Burrows, J. P., and Platt, U.: Continuous monitoring of the high and persistent chlorine activation during the Arctic winter 1999/2000 by the GOME instrument on ERS-2, J. Geophys. Res., 107, 8267, doi: 10.1029/2001JD000466, 2002.
Wahner, A., Tyndall, G. S., and Ravishankara, A. R.: Absorption cross-sections for $\mathrm{OClO}$ as a function of temperature in the wavelength range 240-480 nm, J. Phys. Chem., 91, 2734-2738, 1987. 